\title{
GEDAGTES OOR DIE ONBEPAALDHEIDSBEGINSEL VAN HEISENBERG.
}

Van filosofiese syde en ook deur populariserende skrywers is daar al baie geskryf oor die onbepaaldheidsbeginsel in die Fisika, wat deur Heisenberg in die twintiger jare na vore gebring is. Ons wil nou hier op die gedagte ingaan of meestal nie in hierdie beginsel meer gesien word en met die afleidings vanuit die beginsel verder gegaan word as wat dic beginsel self inhou nie.

Gewoonlik word die onbepaaldheidsverband tussen die posisie en momentum van 'n massadeeltjie ingevoer aan die hand van enkele gedagte-eksperimente. Byvoorbeeld word 'n elektron beskou wat deur 'n mikroskoop waargeneem moet word. Omdat die elektron so klein is en ons sy posisie taamlik goed wil vasstel met die mikroskoop, gebruik ons lig met 'n baie kort golflengte, nl. gammastrale. Dic elcktron sal dan ,gesien" kan word as dit van die gammastrale in die openingshoek van die mikroskoop in verstrooi. Verstrooiing van 'n gammakwant vind plaas deur 'n rigtingsverandering van die kwant by botsing teen die ligte elektron, wat dan 'n sekere momentum bykry. Die strooiproses bring dus ' $n$ verandering in die toestand van rus of beweging van die betrokke elektron mee. Die momentum aan die elektron oorgedra sal 'n sekere spreiding vertoon, wat bepaal word deur die rigting waarmee die verstrooide gammastraal die openingshoek van die mikroskoop ingegaan het. Hierdie spreiding of onbepaaldheid van die momentum van dic elektron na waarneming vermenigvuldig met die onbepaaldheid in dic bepaling van sy posisie blyk van die orde van die konstante van Planck $\left(h=6.6 \times 10-10^{2 *}\right.$ erg.-sekonde) te wees.

Hierdie eksperiment gaan dus van die gedagte uit dat ons nie presies weet en ook nie deur 'n meting kan bepaal in watter rigting die gammastraal die openingshoek van die mikroskoop binnegaan en dus die momentum aan die elektron gegee nie. Indien ons byvoorbeeld die rigting van verstrooiing van die gammastraal of van die elektron by elke waarnemingsproses kon vasstel, sou daar geen onsekerheid in momentum en posisie van die elektron by die meting bestaan het nie. 'n Poging om eksperimenteel die verstrooirigtings van die gammastrale en elektron by die waarnemingsproses vas te stel, om sodoende meer van die momentum van die elektron agter te kom, sal alleen nog ' $n$ verdere onbepaaldheid aan 
die meetresultate toevoeg. Ons moet dus aanneem dat hierdie eksperiment resultate gee met 'n onbepaaldheid wat eksperimenteel nie verhaalbaar is nie. Ons growwe meetapparatuur bring dus storinge by die verskynsel wat ons wil meet. Die storinge vind hulle uitdrukking in die onsekerheidsbeginsel van Heisenberg.

Laat ons as tweede geval die atoom soos Bohr dit die eerste aan ons voorgestel het gaan bekyk. Bohr het die beweging van die negatiewe elektron om die positiewe kern van 'n aloom beskou soos die planete om die son beweeg. Die afmetings van die sirkelvormige kwantumbane en die elliptiese kwantumbane soos deur Sommerfeld en Wilson bereken vir die beweging van die elektron, kan presies uit die teorie bereken word en blyk van die orde van 'n honderdmiljoenste van 'n sentimeter te wees. Probeer ons nou om die afmetings van hierdie bane eksperimenteel te bepaal, sal ons deur die meting van die elektrone om die atoomkern totaal versteur. Empiries het die presiese afmetings van die kwantumbane van elektrone dan geen sin nie. Ons kan dus nie nagaan of die elektrone werklik in vaste bane on die atoomkern beweeg nie.

Terwyl die meganiese atoomvoorstelling van Bohr, ook soos uitgebrei deur Sommerfeld en Wilson o.a., buitendien alleen in enkele gevalle bevredigende resultate gee, is al spoedig omgesien na 'n nuwe teoretiese beskrywingsmetode van die atoom. In plaas van die elektron as ' $n$ massadeeltjie te sien, word dit nou deur 'n golfbeweging beskryf. Hierdie beskrywing bring mee dat die posisie van 'n elektron om die atoomkern deur 'n statistiese spreidingsfunksie gegee word. Die fisiese interpretasie hiervan is dat as ons op 'n bepaalde tydstip 'n meting sou uitvoer, daar 'n sekere kans is dat ons die elektron in 'n bepaalde posisie sou aantref. 'n Groot reeks metings sou dan dieselfde spreiding in posisie moet gee as die teorie. Nou het ons ooreenstemming wat die posisie aangaan tussen de teorie en die eksperimentele moontlikhede, wat nie die geval by die Bohteorie was nie. Hierdie golfteoretiese beskrywing van die atoom blyk dan ook baie vrugbaarder te wees as dic meganiese beskrywing van Bohr.

Terwyl in die Fisika daar altyd 'n noue wisselwerking tussen dic eksperiment en teorie moet bly bestaan, moet die teorie wat die eksperimentele verskynsels in hom opneem en korreleer, wel deeglik rekening hou met die meetbare. Die uit die teorie afgeleide fisiese wêreldbeeld is dus nie noodwendig die werklikheid ne.. Ons kan dus ook nie sê dat die 
atoon werklik so lyk as wat ons uit die golfteoretiese beskouing sou aflei nie.

In die aksiomatiese aanvoring van die golfmeganika is Heisenberg se onbepaaldheidsbeginsel vervat. Inderdaad aanvaar die teoretiese fisika die onbepaaldheidsbeginsel as beginsel vir atomêre teorieë. Dit is daarom dan ook dat die meeste geskrifte oor dic fisika hierdie beginsel sien as 'n onbepaaldheid in die fisiese prosesse self. Na my mening moet ons die beginsel sien as ' $n$ beperking op ons eksperimentele waarnemingsen meetvermoë, wat dan deur die teoric oorgeneem is.

P.U. vir C.H.O.

P. H. STOKER

(Oud-student V.U.). 